\title{
28- Yaşar Kemal’in öykülerinde değerler
}

\section{Menekșe YAVUZ}

APA: Yavuz, M. (2021). Yaşar Kemal'in öykülerinde değerler. RumeliDE Dil ve Edebiyat Araştırmaları Dergisi, (25), 439-451. DOI: 10.29000/rumelide.1036566.

$\ddot{\mathbf{O} z}$

Yaşadığımız toplumla şekillenen insanî değerler, sosyo-kültürel aitlik açısından bir toplumu ayakta tutan en önemli yapı taşıdır. Toplumsal değerler olarak ele alınan; saygı, sevgi, anlayış, hürriyet, hak, hakkaniyet, eşitlik, yardımlaşma, dayanışma, dürüstlük, çalışkanlık, şefkat, merhamet, dayanışma kavramları aynı zamanda önemli birer kültürel miras niteliği taşır ve yeni nesillere ulaştırılması gereken önemli ahlâki ve toplumsal değerler arasında sayllır. Değerlerin nesilden nesile aktarılmasında edebiyat önemli bir rol üstlenir. Yaşar Kemal, eserlerinde çocukluğunda yaşamını sürdürdüğü çevrede maruz kaldığı birçok olayın şahitliği ile insanî ve toplumsal değerler adına birçok konu işlemiştir. Değerlerin toplumsal rolünün incelendiği bu çalışmada; Yaşar Kemal öykülerinde, adalet, hakkaniyet, barış, eşitlik, hürriyet, demokrasi, toplumsal refah ve insan haklarına dair değerlerle öykülerini harmanlamıştır. Hayat verdiği iyi ve kötü karakterlerle vicdan muhakemesinin yapılmasına ve insanî değerlerin okuyuculara aktarılmasına imkân verdiği tespit edilmiştir. Bu kapsamda eserleri incelendiğinde Yaşar Kemal'in kaleme aldığı karakterlerin, insan sevgisi ve değerleri üzerinde şekillendiğini söylemek mümkündür. İyi ve kötü karakterlere dikkat çektiği öykülerinde Yaşar Kemal, bu iki karakteri çoğu kez karşı karşıya getirerek insanî değerlerin dayandığı kaynakları, doğru ve yanlışı okuyucuyla buluşturur, hayatlarını şekillendirmelerinde yol gösterici bir rol üstlenir. Öykülerinde ayrıca Anadolu insanının yoksullukla, olumsuz çevre koşullarıyla nassl mücadele verdiğini anlatırken Çehov öykücülüğünü andırır. Anlatılarında içten samimi bir 'ben' vardır. İnsanların kendilerini kaptırdıkları düzenin acımasızlığını, bu düzende devletin yapamadıklarını yahut eksik yaptıklarını, derin bir anlamsal keskinlik ve yergi ile Anadolu insanını anlatır.

Anahtar kelimeler: Yaşar Kemal, edebiyat, toplumsal değerler, öykü

\section{Values in the short stories of Yaşar Kemal}

\begin{abstract}
Human values shaped by the society we live in are the most important building blocks that keep a society alive in terms of socio-cultural belonging. Considered as social values; The concepts of respect, love, understanding, freedom, right, fairness, equality, cooperation, solidarity, honesty, hard work, compassion, mercy, solidarity are also important cultural heritages and counted among the important moral and social values that should be conveyed to new generations. Literature plays an important role in transferring values from generation to generation. Yaşar Kemal, in his works, has covered many subjects in the name of human and social values, witnessing many events he was exposed to in the environment he lived in his childhood. In this study examining the social role of values; In his stories, Yaşar Kemal blended his stories with the values of justice, equity, peace,
\end{abstract}

Öğr. Gör., Haliç Üniversitesi, Türkçe Öğretimi Uygulama ve Araştırma Merkezi (İstanbul, Türkiye), menekseyavuz@halic.edu.tr, ORCID ID: oooo-00o3-126o-4349 [Araştırma makalesi, Makale kaylt tarihi: 04.10.2021kabul tarihi: 20.12.2021; DOI: 10.2900o/rumelide.1036566]

Adres $\mid$ Address

RumeliDE Dil ve Edebiyat Araşturmalar Dergisi $\quad$ RumeliDE Journal of Language and Literature Studies Osmanağa Mahallesi, Mürver Çiçeği Sokak, No:14/8 Osmanağa Mahallesi, Mürver Çiçeği Sokak, No:14/8 Kadıköy - ÍSTANBUL / TÜRKIYE 34714 Kadıköy - ISTANBUL / TURKEY 34714 e-posta: editor@rumelide.com e-mail: editor@rumelide.com, tel: +90 505 7958124, +90 2167730616 phone: +90 505 7958124, +90 2167730616 
equality, freedom, democracy, social welfare and human rights, and it has been determined that he allows the judgment of conscience and the transfer of human values to the readers with the good and bad characters he brings to life. In this context, when his works are examined, it is possible to say that Yaşar Kemal is shaped on the characters, human love, values and tolerance. In his stories in which good and bad characters draw attention, Yaşar Kemal often brings these two characters face to face, bringing together the sources of human values, right and wrong, and plays a guiding role in shaping their lives. While telling how Anatolian people struggle with poverty and adverse environmental conditions in his stories, he also reminiscent of Chekhov's storytelling, while telling how Anatolian people struggle with poverty and adverse environmental conditions. There is a sincere 'I' in his narratives. It tells the Anatolian people with a deep semantic sharpness and satire, about the cruelty of the order in which people have lost themselves, what the state could not do or what was done incompletely.

Keywords: Yaşar Kemal, literature, social values

\section{Giriş}

Edebiyatta toplumsal ve sosyo-kültürel boyutun varlığı bakımından roman ve öykülerin yeri ayrıdır. Roman ve öykülerde toplumsal gerçeklik tüm şeffaflı̆̆ ile okuyucuyla buluşturulur, birey ve toplum arasındaki problemler ele alınır. Türk edebiyatının toplumsal şartlar ile paralel olarak gelişim ve değişim gösterdiği bir gerçektir. Toplumsal değişmenin, hürriyet isteklerinin, demokratik atılımların yoğunluk gösterdiği dönemlerde edebî türlerden roman ve öyküye olan ilgi artar.

1950'den sonra öne çıkan en önemli isimlerden biri olan Yaşar Kemal’in çok sayıda eseri uluslararası alanda tanınır olmuştur. Eserleri, Cumhuriyet döneminde Türkiye'nin mevcut gerçekliğine dair çok sayıda sosyal olgu ve sembolü içerisinde barındırır. Eserlerin coğrafyası, Çukurova'dan başlayıp İstanbul'a kadar uzanan geniş bir yelpazeyi kapsar. Bu bağlamda eser içerikleri ağalık, eşkıyalık, mübadele, fakirlik, kırsal yaşam, savaşların insanî sonuçları yanında çok sayıda toplumsal olgulardan meydana gelir. Öykülerinde de toplumsal anlamda dışlanmış, güçsüz, hakkı yenen, ayrımcılığa maruz kalan insana dikkat çeker. Tanıklık ettiği toplumsal ve tarihsel olayları öykü karakterlerine uyarlar ve bu anlamda toplumsal meseleleri yansitır.

Bilhassa dil bakımından yetkinliği, sosyo-kültürel bakımdan karakter meydana getirmedeki becerisi, roman kurgusundaki yeteneği ve toplumsal duyarlılığı ile Yaşar Kemal'in edebiyat dünyasında önemli bir yeri vardır. Bu çalışma ile Yaşar Kemal'in öykülerinde okuyucu ile buluşturduğu "değerler" i nasıl ele aldığı, okuyucuya nasıl aktardığı, sembol ve öğeleri ne şekilde kullandığı analiz edilmiştir.

\section{Toplumsal yaşamda "Değer" kavramı ve önemi}

Değerle ilgili tanımlamalar, disiplinler arası farklılık gösterir. Felsefe alanında değer; "özne veya zihnin teorik açıdan tavır ya da yöneliminin yanı sıra pratik bir yönelim” olarak ifade edilir. "Değer” öznenin kendisine, kişisel amaç ve eylemleri dışında kendi özelliklerine ek olarak sonradan edindiği bir özelliktir. Değerler, kişiler tarafından nesnelleştirilmektedir (Güngör E. , 1993). Değerler, bilhassa felsefe ve sosyal bilimlerin ele aldığı en önemli kavramlardan biridir. Bu bağlamda değerlerle ilgili geniş bir literatürden bahsetmek mümkündür. Toplumsal hayatı açıklamak hususunda değer kavramı sosyolojik kaynaklarda sıklıkla kullanılmaktadır (Avcı, 2007).

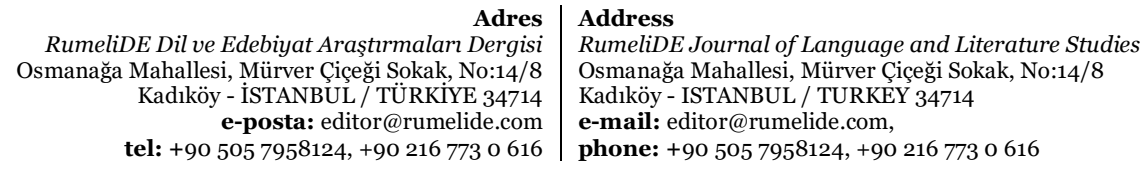


Sosyal bilimler literatüründe değerler, farklı yönlerle ele alınır ve dolayısıyla birbirinden farklı şekilde tanımlanır. En yaygın tanımlamalarda değerler; istenilen, bireylerin hayatlarında kılavuzluk görevi gören, önem dereceleri göreceli olan hedefler olarak ifade edilir. Değerler, sosyal ahlak çerçevesi içerisinde ele alınmaktadır (Güngör E. , 2010). Değerlerin psikolojik bakımından öne çıkan tanımlamalarında ise toplumda herkesin amacının olması, kişilerin kendilerinin de eylemlerinin seçimini meşrulaştırılması için kullanılan ölçütler olarak ifade edildiği görülmektedir. Genelleştirilmiş inançlar olarak ele alınan değerler, Lenski tarafından iki grup olarak sınıflandırılmıştır; Pragmatik ve İdeal Değerler. Pragmatik değerler, bir toplumu oluşturan üyelerin sosyal yaşamlarını devam ettirmeleri için birbirlerine muhtaç oldukları inançlardan kaynaklanan hem bireylerin hem de toplumun yararlarını kapsayan, uygulanma olanağı ideal değerlerden daha fazla olan; "hırsızlık yapmamak, dürüst olmak, çalışkan olmak, güven vermek gibi ahlaki değerler bu sınıfta ele alınmaktadır. İdeal değerlerde ise; "bütün insanlar kardeştir", "herkesi kendini sevdiğin şekilde sev" gibi gerçeklikte uygulanma durumu daha düşük, daha çok hayali paradigmalara yakın beklentilere dair inançlar olarak ifade edilmektedir (Göz, 2014).

Değerler, insanlığın varlı̆̆ından bu yana gündemde olan kavramlardan biridir. Değerler; bireyler tarafından kabul edilen, hedef, amaç ve maddi / manevi, pozitif veya negatif anlamda benimsenmiş ve insanların yaşamlarında aktif olan olgulardır. Toplum varlığını devam ettirmek için değerlere gereksinim duyar.

Toplumsal yapının bir düzene tabi olması kümeleşmenin alelâde bir toplum yığını olmadığını kanıtlar. $\mathrm{Bu}$ anlamda her toplumun değerlere ihtiyacı vardır. Değerler, kültürle özdeşleşerek diğer kültürlerden farklılaşır. Bu minvalde değerler, kültürü diğer toplumlardan ayırarak, devlet sınırları içerisinde milli birlik ve beraberlik kavramlarını pekiştirir. Toplum açısından kabul görmüş hal ve hareketler, düşünce ve bakış açlları bireyler dışında gelişir. Bu nedenle toplumsal bilincin zaman zaman kişisel bilince dayatmalarda bulunduğu, kişileri şekillendirmeye çalıştı̆̆ı iddia edilir. Dolayısıyla toplumsal değerlerin, zorlayıcı bir yanının olduğu ve kendilerini kabul ettirme konusunda baskıcı olduğunu söylemek mümkündür.

Toplumların her birinde genel değerler kapsamında hüküm, karar ve görüşlerin tanımlandı̆̆ı yargılar bulunur. Bir toplum içerisinde kişilerin birbirleri arasında ilişkilerini yönlendiren, erdemli davranışlar olarak nitelendirilen değerler, insanların temel hak ve özgürlüklerinin günlük hayat içerisinde uygulanmasını, ihlallerinin ortadan kaldırılmasını hedeflemektedir. Bu anlamda toplumsal değerler insan hakları ile de doğrudan ilişkilidir. Toplumsal değerlerini benimseyen ve yaşamını bu anlamda yönlendiren kişilerin evrensel değerlerin uygulamasında da etkisi yadsınamaz bir gerçektir. (Keskin, 2016)

Toplumsal değerler olarak ele alınan; saygı, sevgi, anlayış, hürriyet, hak, hakkaniyet, eşitlik, yardımlaşma, dayanışma, dürüstlük, çalışkanlık, şefkat, merhamet, dayanışma kavramları aynı zamanda önemli birer kültürel miras niteliği taşımakta ve yeni nesillere ulaştırılması gereken önemli ahlakî ve toplumsal değerler arasında sayllır. Bu değerleri benimseyen ve özümseyen kişilerden meydana gelen toplumların, insan hakları ve özgürlükleri açısından çok daha sorunsuz medeniyetler olacağı düşünülür. Bu nedenle toplumsal değerlerin yeni kuşaklara aktarımı için çeşitli çalışmalar gerçekleştirilmekte, kültürler arası iletişim ile bu değerlerin varlığını sürdürme konusu desteklenmektedir. Millî, ahlâki ve toplumsal değerlerin aktarımında sanat bu anlamda büyük önem taşır.

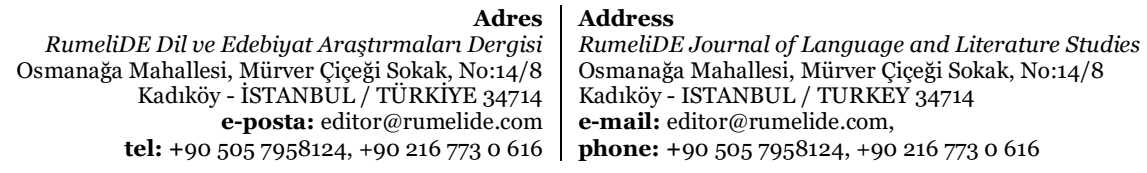


İnsanlar açısından değerler eğitiminin önemi ve gerekliliği, insanların makine ya da robottan öte duygu ve düşünceleri ile yaşamlarını sürdüren varlıklar olmasıyla ilgilidir. İnsanların zekalarının ve fiziksel yatkınlıklarının yanında onların değer veren, sevgi ya da nefret duyan, kıskanabilen, bağlanan, tutkuları olan, kin tutabilen, doğru ve yanlışı ayırt edebilen, kendi doğru ve yanlışlarının çerçevesini çizebilen, karakter sınırlarını belirleyen yönlerinden de bahsetmek gerekir. İnsanların bu yönlerinin doğru şekillerde eğitilmediği takdirde dengeli bir kişilikten söz etmek mümkün olmayacaktır (Kenan, 2007).

Genel olarak tüm tanımlamalarda insan, bilişsel ve mekanik yönleri ile dikkat çeker. Matematik problemi çözebilen, fizik ve kimya alanında başarılı, analitik düşünce sisteminin gelişmiş olması günümüzde insanların gelişmişlik seviyelerinde önemli kriterler olarak belirlenirken; şefkat, merhamet, özveri, vicdan gibi muhakemelerin göz ardı edildiği insanı yalnızca "nitel” boyutları ile bilen ve öğrenen nesillerin ortaya çıması kaçınılmazdır. Değerler eğitimi bu kapsamda kişisel bazda insanı "insan” yapan özellikleri gün yüzüne çıkarırken, toplumsal açıdan da büyük önem taşımaktadır. Birbirinden farklı birçok karakteri içerisinde barındıran bir toplumda, toplumsal ve insanî değerlerin bilincinde, karakteri sağlam olan kişilerin çokluğu toplumlar için son derece önemlidir (Meydan, 2014).

Bugün bir toplum içerisinde her alanda gözlemlenen ahlaki gelişmişliğin yetersizliği neticesinde ortaya çıan olumsuzluklardan, hemen hemen tüm bireyler rahatsız olmakta ve bu durum her firsatta dile getirilmektedir. Günümüz toplumlarında özellikle çocuk ve gençlerde çok daha fazla ortaya çıkan şiddet, saygısızlık, kötüleşen gençlik eğilimleri, hırsızlık, saldırganlık, madde bağımlılı̆̆ı, argo kullanımı, sorumluluktan kaçış, erken cinsellik ve cinselliğin kötü kullanımı, aile birlik ve beraberliklerindeki bozulmalar, kitle iletişim araçlarındaki kullanım ve erişim yaygınlığı toplumlarda değerler eğitimine verilen öneminin artmasını gerekli kılmaktadır.

\section{Toplumsal “Değerler”de edebiyatın rolü}

Toplumsal değerler, kişilerin davranışlarını yönlendiren ve davranışlarını yargılayan olgulardır. Değerler bir toplumun, beklentilerini, ilgilerini, önemsedikleri ve üzerinde durdukları hususları göstermektedir. Kişilerin davranış biçimlerinde "ideali” ortaya çıaran toplumsal değerler; kültürün en önemli yapı taşı olarak ifade edilmektedir. Toplumların zaman içerisinde birikimleri sonucunda ortaya çıkan değerlerin yine zaman içerisinde değişime uğraması kaçınılmazdır. Kültürler arası da farklılık gösteren değerler, toplum tarafindan aynı paralelde kabul görmüş standartların tamamı olarak ifade edilir (Demiryürek, 2015).

Toplumsal değerler, ortaya çıtıkları milletlerin aynası görevinde olduğu için milletten millete farklılık gösterir. Bir toplum tarafından en çok ihtiyaç duyulan unsurlar, toplumun değer yargılarını meydana getirerek varlıklarını devam ettirmelerini sağlamaktadır. İhtiyaçların birbirinden farklı olması, her toplumun kendine ait kültürel ve toplumsal değerlerinin ortaya çıkmasına yol açmıştır. Fakat bazı değerler evrensel olarak kabul görmektedir. Temel eğitim olarak okullarda kişilere aktarılması amaçlanan evrensel değerlerin eğitim-öğretimin tamamlayıcı unsuru olarak sınırlandırılması mümkün değildir. Toplumsal değerler ile ilgili eğitimler çocuğun doğumu ile başlamakta ve ölümüne kadar yaşamının tüm evrelerinde devam etmektedir. Değerlerin bu anlamda kişilere aktarılması, o günün şartlarına adapte olunması açısından da büyük önem taşır. Böylelikle kişiler bireysel ve sosyal açıdan gelişimlerini sağlar. Kişi, toplumsal değerlerle hayatında doğru ve yanlış seçimi yapmakta da tereddüt yaşamayacak ve hayatını bu değerler ile şekillendirecektir. Toplumsal değerler bu anlamda toplumsal düşünce ve davranışların da temelini oluşturmaktadır (Akbalık, 2015). Bu bağlamda, toplumsal değerlerin ve kültürlerin yeni nesillere ulaştırılmasını sağlamak bir milletin varlığı açısından büyük 
önem arz ettiğini söylemek mümkündür. Toplumsal değerlerin aktarımı ilk olarak bir insanın dünyaya geldiği aile ile başlamaktadır. Aile, sahip oldukları tüm toplumsal değerlerini çocuklarına aktarmak ile mükelleftir. Toplumsal değerler, kültürel ve toplumsal devamlılığın sağlanması açısından büyük önem taşır. Aynı zamanda, çocuğun soyut düşünme kabiliyetine erişmesiyle birlikte bu değerlerin öğrenilmesinin önemi de anlaşılmaktadır.

Küreselleşmeyle birlikte iletişim teknolojilerinde yaşanan gelişmeler sonucu kişiler yaşamın her evresinde toplumsal değerler ile karşı karşıya kalır. Toplumsal değerlerin kişilere aktarımında iletişim cihazlarına sıklıkla başvurulur. Kişilere günümüz bilgi çağında birtakım bilgilerin aktarımı yapılırken kişiyi her yönü ile toplumun bir üyesi haline getirme ve milli birlik beraberlik duygularını aşılama amacı taşınması gerekir. Çocukların kişilik gelişimi, kişisel sorumluluk bilinçleri bu değerlerin ne kadar doğru aktarıldığı ile yakından ilişkilidir. İlk önce aile ortamında sonra eğitim-öğretim hayatı içerisinde millî ve manevî değerleri tanımaya başlayan kişi, yaşanan teknolojik gelişmelerle birlikte bu eğitimi almaya çeşitli ortamlarda devam edebilir. Millî ve manevî değerleri yeterince tanımayan biri, geçmişle bağlantısını koparırken aynı zamanda bulunduğu çağa uyum sağlamada da problemler yaşamaktadır. Kişilik gelişiminde de bu durum olumsuz bir etmen olarak karşımıza çıkar. Kişinin kimliği ve kişiliği millî değerlere sahip çıkışı ile gelişim gösterir ve kişi bu değerlerle topluma karşı sorumluluk duygusu kazanır (Demirtaş, 2012). Günümüzde tüm toplumların amacı kendi değerlerini öğrenen, bilen, tanıyan, uygulayan ve yaşatan kişiler yetiştirmektir. Milli değerler bu anlamda kişilerin içinde yaşadıkları toplumla sentezlenmesini sağlayarak sosyo-kültürel açıdan aitlik duygusunu yeşertir.

İçerisinde barındırdıkları mesajların zenginliği ile edebiyat milli kültürel değerlerin diğer nesillere aktarımında evrensel bir kaynak rolü üstlenmektedir. Edebiyatın temel işlevlerinden biri bir topluma ait kültürün okuyucular ile buluşturulması ve öğrenilmesinin sağlanmasıdır. Bir diğer temel işlevi ise okuma-yazması olmayan kişilerde toplumsal değer ve ahlâki eğitimi üstlenmektir. Bu doğrultuda özellikle pedagojik bir araç olarak kullanılan folklor, içinde barındırdığı masallar ve ninniler ile çocukları bir bakıma disiplin altına alarak kişiliklerinin iyileştirilmesinde önemli rol oynar. Ahlâki semboller içeren edebî ürünler, kişilere iyi davranışları tembihlemek için kullanılır. Edebiyatın önemli bir diğer işlevi ise kabul edilmiş davranışları nesilden nesle ulaştırmaktır. Davranış ve inançların altını çizmenin yanında sosyal kontrolün sağlanması açısından da büyük önem taşıyan edebiyat, sosyal uyumun sürdürülebilmesinde önemli bir rol üstlenir (Aydın \& Akyol Gürler, 2012).

Günümüzde hızla gelişen, değişen ve dönüşen teknolojik ürünler, kişiler arası sosyal ilişkileri giderek zayıflatır. Edebiyat ürünleriyle bu ilişkilerin yeniden güçlendirilmesi mümkündür. Kişilerin aile ve sosyal çevre ile etkileşimlerini sağlayan, yardımlaşmayı, iyiliği, sevgi ve saygıyı, dürüstlüğü aşılayan edebî eserler, özellikle toplumsal değerlerin hayat bulmasında ve devamlılı̆̆ının sağlanmasında çok önemlidir. Her edebî eserin okuyucuya anlatmak istediği mesajının olduğu bir gerçektir. Bu anlamda edebiyat ürünleri içerisinde değerler eğitimini barındırmaktadır. İnsan hayatında tartışmasız bir öneme sahip kitaplar özellikle çocukluk döneminde kişilerin hayatında yer edinmeye başlamaktadır. Kişilerin henüz çocukluk çağındayken duyarlı bir düşünce yapısına sahip olması, nitelikli kitaplar okuması ile doğru orantılıdır. Bir milletin ilk önce çocuk edebiyatına sonrasında toplum edebiyatına dair ürünleri, ilgili milletin gelecek beklentisi ile yakından ilişkilidir. Bu nedenle öğretim çağında kişilere kazandırılması hedeflenen toplumsal değerlerin edebî ürünlerle aşılanması tartışmasız kabul edilmektedir (Şimşek, 2015).

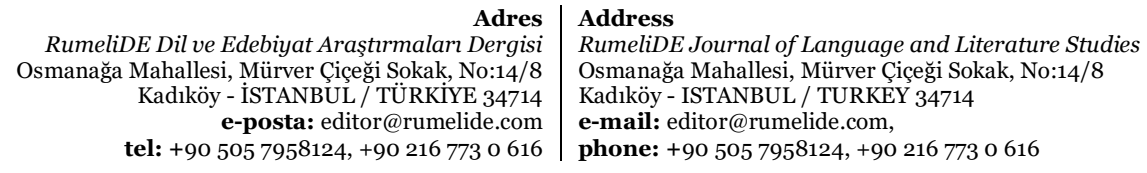




\section{Roman ve öykülerde toplumsal değerler}

Eğitim ve öğretim hayatı, kişilerin bilişsel ve motor becerilerinin gelişmesinde önemli bir rol oynar. Bir bireyin her anlamda gelişmesini destekleyen en önemli unsur şüphesiz ki ailesidir. Eğitim hayatının başlamasıyla birlikte çevresi de genişlemeye başlayan bireyin gelişim etmenleri de aynı paralelde genişler. Aynı zamanda küreselleşmeyle iletişim teknolojileri alanında yaşanan gelişmeler bireyler arasındaki bilgi ve deneyim aktarımını da çok daha kolay hale getirmiştir. Fakat bilgiye bu kadar kolay erişilmesi birçok olumsuz sonucu da beraberinde getirir. Özellikle dijital ortamlarda elde edilen bilginin doğruluğunun sorgulanmasının ve bilgi kirliliğinin önlenmesinin gerektiği savunulmuştur. Medyanın olumlu birçok getirisi kadar olumsuzluklarının da olduğunun farkında olan kişiler teknoloji ile ortaya çıkan kültür yozlaşmasına mahal vermek istemese de bazı durumlarda yetersiz kalabilmektedir. Özellikle çevrede yaşanan değişimler dijital teknolojilere olan maruziyeti artırmaktadır. Bu maruziyet, bireylerin kişilerden çok kitle iletişim araçlarına olan ihtiyacını güdülemektedir. Günümüzde kullanımı adeta dayatılan kitle iletişim araçları yaşamın hemen hemen her alanında insanların karşına çımaktadır. Teknolojinin kişinin hayatını olumlu etkilemesi çocukluk çağındaki eğitim ile ilişkilidir (Han \& Türkylmaz, 2020).

Kişiler özellikle iyi ve kötü ayrımını, saygı ve sevgiyi, dürüstlüğü ve sorumluluk bilincini ailesinin toplumsal ve kültürel değer aktarımı ile gerçekleştirir. Değerler, doğuştan gelen olgular olmamakla birlikte, davranışların şekillenmesinde oldukça etkilidir. Anne ve baba davranış şekillenmesinde birey için kilit noktadadır. Fakat zaman içerisinde ebeveynlerin yanı sıra davranış gelişiminde farklı etmenler de ortaya çıkar. Bu etmenler içerisinde edebiyat büyük bir rol üstlenmektedir. Toplumsal ve kültürel değerlerin gerek öğretimi gerekse nesillere aktarımında edebî eserlerin önemi yadsınamaz bir gerçektir. Edebiyat ürünleri, toplumu ayakta tutan iyi ve doğru olarak nitelendirilen değerleri dolaylı yollar ile estetik bir şekilde okuyucuya sunmaktadır (Sallabaş, 2012).

Kişiler, içinde bulundukları toplumlardan birçok yönde etkilenmektedir. Eğitim dönemi ve günlük yaşamları içerisinde okunan edebî eserler ile toplum içerisindeki yerlerini de belirlemektedir. Edebiyat içerisinde roman ve hikâye türü özellikle yorum ve değerlendirme kabiliyetlerini olumlu yönde etkilerken yaşamların da şekillenmesinde önemli bir rol üstlenmektedir. Değerlerin aktarılması sürecinde kişiler ile buluşturulan roman ve öyküler içerdikleri kültürel öğelerin zenginlikleri ile aktarımı çok daha kolay ve eğlenceli hale getirmektedir. Roman ve öykü içeriklerinin, yaşam döngüsü içerisinde karşı karşıya kalınabilecek problemlere verdikleri cevaplar ve tepkiler okuyucuya rehberlik etmektedir. Aynı zamanda insanların birbirinden farklı özellikler taşıyabileceğini, ayrı kültürlerin olduğunu, saygısız duygu ve düşünce örneklerinin varlığını sunarak okuyucunun aynı zamanda kendini tanımasını, diğer insanlar ile kıyaslamasını, benzer ve farklı noktaları yakalamasını, çevresinde yaşanan olayları anlamasını sağlamaktadır. Özellikle kendi toplumunun değer yargıları ile sentezlenmiş roman ve öyküler, dürüstlük, sevgi, başarı, çalışkanlık gibi evrensel değerleri de okuyucuya aktarmaktadır (Özbay \& Kurtuluş Tayşi, 2009). Bu kapsamda toplumun benimsediği değerlerin gelecek kuşaklara aktarımında roman ve öyküler büyük rol oynamaktadır. Yazar, toplumuna dair değerleri eserlerine ne kadar çok sindirirse değer aktarımında da o kadar başarılı bir tutum sergilenmiş olur.

Edebiyat, geçmişten bu yana insanları çeşitli bakımlardan eğitmek, iyiyi ve doğru arasındaki ayrımı ortaya koymak için kullanılan önemli bir araç olmuştur. Edebî eserler toplumu ayakta tutan değerleri estetik bir kaygı doğrultusunda okuyucuya aktaran önemli vasıtalardır. Tanzimat dönemiyle birlikte çoğunlukla şiir ve sözlü geleneğe bağlı olan edebiyat roman ve öykü gibi yeni türler ile zenginleşmeye

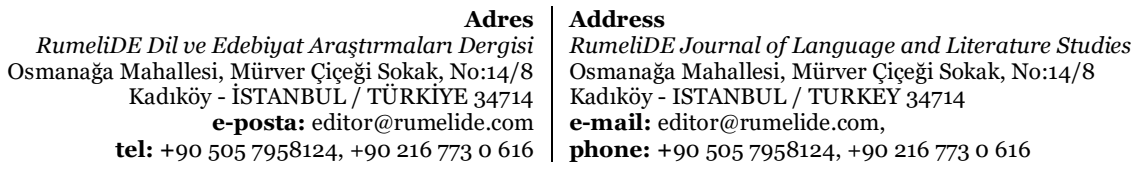


başlamıştır. Tanzimat dönemi, edebî eserlerin çeşitliliğinin artması, makale, deneme, röportaj türlerinin yanında roman ve öykülerin de edebiyat dünyasında yer bulduğu bir dönemi kapsamaktadır.

Günümüzde de edebî eserlerin çoğunda gözlemlendiği gibi değer ve ahlâk öğretimi/eğitiminin Tanzimat dönemi eserlerinde de yer aldığı görülmektedir. Dönem yazarları edebiyatta edebî yönü ikinci planda tutarak edebiyatı toplumun gelişiminde ve eğitiminde önemli bir araç olarak kullanmıştır. Tanzimat döneminde ilk kadın roman yazarı unvanına sahip Fatma Aliye Hanım döneminde ses getiren birçok esere imza atmıştır. Kadın - erkek eşitliği, kadın eğitimi, kadının çalışma hayatındaki yeri, evlilik süreci, İslâm dininde kadının konumu, tek eşlilik - çok eşlilik, boşanma gibi kadının doğrudan ilgili olduğu konular, Fatma Aliye Hanım'ın eserlerinde dikkat çekmektedir (Karaca, 2011). Muhadarat isimli romanı da toplumsal değerler bakımından zengin öğreti değeri bulunan öğeler içermektedir. Roman içerisinde önemli konulardan biri toplum içerisinde ahlâk kurallarına karşı beslenen bağlllık olarak tanımlanan namus kavramı olmuştur. Muhadarat romanı içerisinde Sai Bey, üvey anne Calibe Hanım ve onun amcazadesi Süha Bey tarafından ortaya atılan, Mukaddem’in, sarhoş bir anında evin hizmetçisi Reftar ile gizli bir ilişki yaşadığı ve böylece nişanlısı Fazıla’yı aldattığı yönündeki iftira sonrasında Sai Efendi’nin Kızı Fazıla’ya söylediği cümlelerde namus kavramının dönem içerisinde ne kadar önemli olduğunun altı çizilmektedir:

"Ben senin bunu ne için yaptığımı bilirim ama sen ondan ümidi kes! Mademki lakırdı bu kadar açlld. Ben de sana şunu söyleyeyim ki senin bundan sonra Mukaddem'e varmak ihtimalin yok. Bunu hatırmdan sil de benim vakar ve haysiyetime dokunacak muamelatta bulunayım deme. Ben namus uğrunda değil evlat, canımı feda ederim” (Hanım, 2012).

Halk kahramanlarının mücadelelerin yer verildiği Dede Korkut Hikâyeleri de değer eğitiminin önemli bir aracı olarak göze çarpmaktadır. Dede Korkut Hikâyeleri içerisinde aile birliği, saygı, sevgi, güven, cesaret gibi değerlerle şeref, dayanışma, vatan sevgisi, cömertlik, merhamet, toplumsal ve dinî değerlerin de aktarıldığı görülmektedir (Deveci, Belet, \& Türe, 2013). Dede Korkut Hikâyelerinde kadın ve erkeğin birbirlerine verdikleri önem Dirse Han Oğlu Boğaç Han Hikayesinde Dirse Han’ın eşine söylediği cümleler ile dikkat çekmektedir:

"Beri gel başımın bahtı, evimin taht, evden çıkı yürüdüğünde selvi boylum, kara saçı topruğuna sarmaşanım, kurulu yaya benzer çatma kaşlım.” (Özbay \& Karakuş Tayşi, 2011).

Günümüzde oldukça önemli değerlerden biri olan saygı, Oğuz Türklerinin hayatlarında da önemli bir yerde olmuş ve özellikle devlet büyüklerine olan saygı Dede Korkut Hikâyelerinde sıklıkla vurgulanmıştır. Begil Oğlu Ermen Hikâyesi içerisinde yer alan "Padişahlar Tanrı'nın gölgesidir. Padişahına asi olanın işi rast gitmez." Cümlesi devlet büyüklerine duyulan / duyulması gereken saygıyı aktarmaktadır (Özbay \& Karakuş Tayşi, 2011).

Edebî metinler dilin kullanımı ile hayat bulmaktadır. Öyküler, çok daha az kelime ile çok daha fazla duygunun uyandırıldığı ve okuyucusunun sıkılmadan okuduğu edebî metinler olarak ifade edilir. Türk edebiyatında öyküleri ile tartışmasız bir yere sahip olan Memduh Şevket Esendal'ın eserlerinde değer aktarımı açısından; aile birliği, adalet, özgürlük, barış, çalışkanlık, dayanışma, güven, hoşgörü, misafirperverlik ve duyarlılık değerlerinin üzerinde durulduğu görülmektedir.

Memduh Şevket Esendal, Gödeli Mehmet adlı eserinde; "Parlak bir sema altında bu kocaman çayırda başıboş koşup eğlenen yavrularm hallerini gördükçe İstanbul"un rutubetli bahçelerinde hapsedilen arkadaşlarına derin derin acıdım.” (Esendal M. Ş., 2007), Bir Kucak Çiçek isimli eserinde;

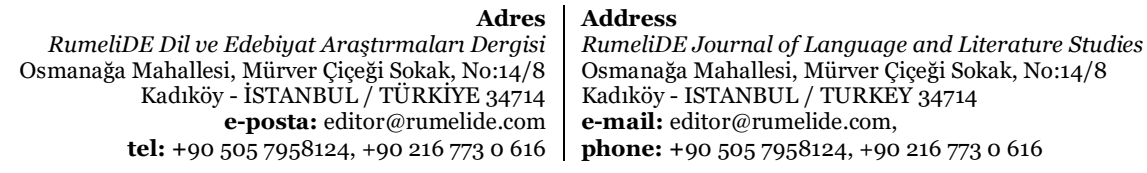


"Birçokları burasını parası için istediler. Ben insanlı̆̆a hizmet için istedim. Ben para kazanmak için hekimlik etmeyi bir alçaklık bilirim. İzmir"de adı lazım değil, büyüklerden biri bir rapor istedi. Ne kadar para istersen vereyim, dedi. Affedersiniz, biz yolsuzluk yapamayı, para için de çalışmiyoruz, dedim. Meslek parayla olmaz.”(Esendal M. Ş., 2005)

Cümleleri ile duyarlılığın altını çizmiştir. Türk öykülerinde önemli yeri olan önemli isimlerden biri de Orhan Kemal'dir. Şiirleri ile edebiyat dünyasına giren Orhan Kemal romanları ve hikâyeleri ile çok daha dikkat çekmiştir. Ekmek Kavgası isimli hikâye kitabında toplumsal gerçeklikleri eleştiren tarzı ilgi uyandırmıştır. Toplumcu gerçekçi bakış açısını kendi gözlem ve eleştiri gözü ile birleştiren Orhan Kemal bu öyküde savaş döneminde askeri birliğin mutfaktaki artık besinlerle karınlarını doyurabilen sefalet içerisindeki insanların açlık korkularını ele almıştır. Toplum içerisindeki güçlü ile ezilen, ağalar ve köylüler, işçiler ve işverenler, zengin ve fakir çatışmaları kaleme alınarak alt tabakadaki kişilerin hayatlarından kesitler yorumlanmıştır. Fakirliğin yanında çaresizlik teması üzerinde de yoğunlaşan Orhan Kemal, sosyal adaletsizliğe de dikkat çekmiştir. Günümüzde hala gerçekliğini koruyan bu hikâyeler toplumsal değerlerin aktarımında da önemli rol üstlenmiştir.

"Koşuyorlar, gidiyorlar, geliyorlar, tutuyorlar, koparıyorlar... Yığın yığın, vıcık vıcık, sürü sürü insanlar... Üzerinize atlıyor, lokmanızı ağzınızdan kapıyorlar Beyefendi. Beyefendi, insanlar kurt gibi, kurtlar gibi saldırıyorlar Beyefendi!”, “Bazen bir kemik parçası yüzünden insanlarla, köpekler arasinda da kavgalar oluyordu.” (Kemal O. , 2008)

Cümlelerinde insanlar arasındaki eşitsizlik, üstünlük taslama, maddiyata yönelme, manevî değerleri göz ardı etme gibi toplumsal sorunlara dikkat çeken eserde, aynı zamanda kadınların toplum içerisindeki yeri, işçi problemleri, çocuk hakları ve çocuk işçileri, şehre çalışmak için gelen insanların maruz kaldıkları sorunları toplumsal değerler çerçevesinde ele alınmıştır.

Türk edebiyat tarihi içerisinde önemli isimlerden bir diğeri olan Sabahattin Ali, öykülerinde toplumsal değerlere yer veren ve toplumsal değerlerin aktarımında akla gelen isimlerden biridir. Sanat anlayışı açısından toplumcu bir yazar olan Sabahattin Ali, öykülerinde toplumsal sorunları ele alırken kent sorunlarından ziyâde köylü kesimin dertlerine yoğunlaşmıştır. Kağnı-Ses isimli eseri içerisinde yer alan Bir Skandal, Köpek adlı öykülerinde ve Yeni Dünya isimli eseri içerisinde yer alan Bir Konferans ve Sulfata adlı öykülerinde aydın ve köylü arasındaki kopuklukları kaleme almıştır. Köpek adlı öyküde;

“Merak ediyorum ayol, ben hiç köylü görmedim ki!” (Ali, 2019) Cümlesi ile aydın kesime mensup bir genç kızın hayatında daha önce hiç köylü görmediğini vurgularken, Sulfata isimli öyküsünde eşi sıtma hastalığına yakalanan bir köylünün kasabadaki doktor tarafından uğradığı hakaretler şu cümleler ile ifade edilmiştir; "Ne laf anlamaz hödük şeylersiniz! Kanun var, nizam var, size yol gösteriyoruz, daha da kafa tutuyorsunuz. Defolun şuradan! ...” (Ali S. , 2003). Değirmen isimli eserinde yer alan Bir Gemici Hikayesi'nde ise işçi ve işveren ilişkilerine dikkat çeken Sabahattin Ali bu öyküde, hakların bilincinde olan bir işçi kitlesini kaleme almıştır. Gemideki kaptan ve mürettebat arasındaki eşitsizliğe tepki gösteren işçiler, hakları için mücadele etmekte ve adaleti savunmaktadır.

\section{Yaşar Kemal öykülerinde "Değerler"}

Edebî bir eserin anlaşılması, sanatçının yorumunun okuyucu tarafından değerlendirilmesiyle mümkündür. Modern Türk roman ve hikâyelerinde büyük ustalardan biri olarak nitelendirilen Yaşar Kemal, bir toplumu ilgilendiren her değeri eserleri ile harmanlamış ve okuyucusuna sunmuştur. Özellikle insan sevgisi ve özgürlük değerlerini aktardığı eserlerinde sevgi, hakkaniyet, ümit ve özgürlük öğelerini kendi yorumu ile paylaşır.

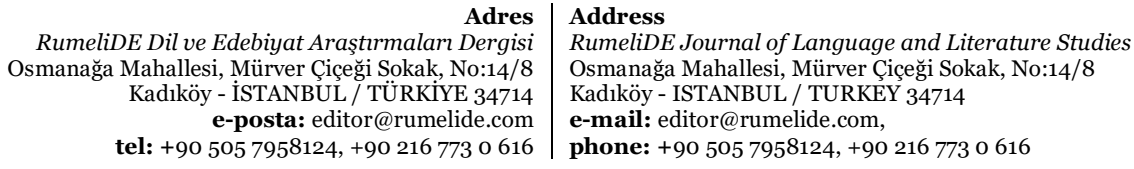


Yaşar Kemal genel olarak eserlerinde yaşanmış olaylara değinir. İnsanların hayat tecrübelerini işlerken, okuyucuya olayları kendi yorumu ile sunmaktadır. Çoğunlukla umutlu, korkuları ile başa çıabilen, sevgi dolu karakterler ile okuyucu arasındaki bağı kuvvetlendirirken insan ve toplumu derinden etkileyen sorunlara yoğunlaşır. Çoğu zaman Çukurova eşrafında şekillenen olaylara kendisinin de tanıklık ettiğini gördüğümüz eserlerinde Yaşar Kemal, toplum tarafından dışlanmış, güçsüz görülmüş, hakkı yenilmiş karakterlerin yanında durmaktadır (Nichanian, 2011). Yaşar Kemal eserlerinde insancıl bir felsefe ile toplumsal değerlerin aktarımında oldukça başarılı bir anlatım sergiler. Genellikle Çukurova ağalarının hikâyeleri ile şekillenen Yaşar Kemal eserlerinde insan ölümüne neden olan karakterler olduğu kadar ölüme karşı duran ve sevgi ile bütünleşmiş karakterler de yer alır.

Yaşar Kemal ilk uzun hikâyesini 1943 senesinde askerlik döneminde kaleme almıştır. Pis Hikâye, Bebek, Dükkancı isimli öyküleri Yaşar Kemal tarafından yazılan ilk hikayelerdir. 1952 senesinde Sarı Sicak kitabında toplanan bu eserler 1965 sonrasında kaleme aldığı diğer öykülerin eklenmeleri ile Sarı Sıcak Bütün Hikâyeler ismini almıştır. Yaşar Kemal'in genel olarak eserlerinde tarımdan sanayiye geçiş sürecinde olan Türkiye'nin yaşadığı toplumsal sıkıntıları Çukurova'dan yola çıarak okuyucuya aktarır. 22 öyküden oluşan bu eser içerisinde genel anlamda sefalet, fakirlik, şiddet, dayanışma, yardımlaşma, yozlaşma, doğa sevgisi, cinsellik gibi temalar işlenmiştir.

Yaşar Kemal öykülerinin insanların çaresizliğine ve yoksulluğuna dikkat çektiği görülür. 1944 senesinde ilk öyküsü olarak bilinen "Pis Hikâye" Yaşar Kemal’in klasikleri arasında yer almaktadır. Günümüzde hala karşıllğı bulunan trajedilere yer veren bu eserde işlenen kırsal dünya içerisindeki ahlâk anlayışı ile namus kavramı üzerinde durularak bir köyde toplumsal ve kişisel pisliklerin yok edilme mücadelesi okuyucu ile buluşturulur. Öyküde dikkat çeken, dağ köylerinden getirdiği kadınları satan Cabbar Gülenoğlu'nun köylünün cesaretlendirmesi ile Fas Osman'a sattığı avrattır. Fas Osman'a bu hediyeyi alan ablası Hürüce Kadın'dır. "Yeter ki avrat gibi malın olsun elinde. Kim olsa kapışır. Yüz lira ne ki yani, hem tarlada işini görür, hemi evde, hemi yatakta.” (Yaşar, Pis Öykü, 2007) Cümleleri ile kadın, cinsel obje olarak nitelendirilen, metalaştırılan, üzerinden para kazanılan ve cinsel ihtiyaçları tatmin eden bir mal olarak dikkat çekmektedir. Fadık’ın hikâyesine ev sahipliği yapan bu eser çok eski görünse de insanların varoluşundan bu yana karşı karşıya kaldıkları trajik olaylar bakımından tazeliğini maalesef günümüzde de korur.

İnsan sıcaklığıyla Çukurova üzerinden değindiği hikâyeleri topladığı Sarı Sıcak kitabı içerisinde yer alan öykülerde genel olarak insanların küçük hayalleri için ne denli bedeller ödedikleri yansıtılmaktadır (Erden, 1993). İnsanların yoksullukla mücadele ederken bu arada oradan oraya savrulan ve hayatın içerisine erkenden atılan çocuklar ve kadınların kaleme alındığı Sarı Sıcak eserinde Yaşar Kemal'in gerçekçiliği ön plana çıkar. Kitapta yer alan öykülerde çok sıradan ihtiyaçların veya düşük maliyetli hayallerini gerçekleştirmek için minik bedenleri ile büyük mücadelelere giren çocukların acıklı dramları özellikle dikkat çeker.

Sarı Sıcak eserine ismini veren öyküde küçük bir çocuk olan Osman'ın küçük yaşta yakıcı sıcak altında tarlada çalışmak zorunda olduğu anlatılır (Yaşar, 2007). Günümüzde de hala çocuk yaşta hayatın içerisine atılmak mecburiyetinde olan, okul yerine işe giden ve aile geçimine ortak olan birçok çocuk bulunmaktadır. Toplumsal gelişimin en önemli göstergelerinden biri olan eğitimde aksamalara yol açan çocuk işçiler bugün de hala toplumda kanayan bir yaradır. Öykülerde çocukların gerek bedensel gerekse duygusal olarak maruz kaldıkları şiddet dikkat çekmektedir.

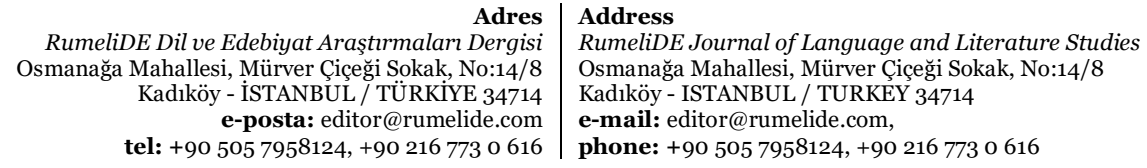


Yaşar Kemal'in eserinde ana isim olarak kullandığı "Sarı Sıcak" ismi içerisinde geçen "sarı" rengi hüznün, hastalığın ve yoksulluğu temsil eder. Aynı zamanda güzellikler ve başkaldırılar da diğer renklerin dilinden yola çıkarılarak betimlenir. Masmavi gökyüzü, ak ak leylekler, pespembe yanaklar, kızıl kan... Bu nedenle öykülerde yalnızca toplumun gerçekleri değil dilin ustalıklı kullanımı da (ya da) dilin çağrışım zenginliği de dikkat çeker.

İstanbul'da geçen Ağır Akan Su isimli öyküsü ise Kerem Usta isimli başkahraman ile hayatında olan hiçbir şeyi seçme şansı olmayan karısı ile bu küçük dünyalarında ne kadar mutlu olduğunu anlatır. Her işte çalışan, evlendiği kadını ve çocuklarını seven, oturduğu gecekondudan memnun olan Kerem Usta'nın karısı çalışmak için Almanya'ya gitmiştir. Zamanla karısı hakkında çıkan dedikoduların dozu giderek artmış hatta bu dedikodular karısının Almanya'da çocuk sahibi olduğuna kadar varmıştır. Bu dedikodular ile deliye dönen Kerem Usta Almanya'ya gidip karısını öldürmeyi düşünse de sonrasında vazgeçer:

"Dayan Kerem Usta, dayan iki gözüm, dayan kardaşım. Yüreğini dört okka eyle. İnsanın her şeysiyle, tüm alçaklı̆ıyla başa çıkarsın, kendi kendini aşağılamış, kendini kandıran insanın aşağılaşmasıyla başa çıkamazsın. Dedikodu yapan insan dedikodu yaptığını bilir, onun aşağılık bir iş olduğunu da bilir... Kendi gözünde kendini aşağılar. Bu insanı kendisi kadar kimse aşağılayamaz. Onun için dayan aslanım, dayan Kerem Ustam, dayan elleri güzelim...” (Kemal Y. , 2007)

Cümleleriyle aynı zamanda Kerem Usta’nın diğer insanlar tarafından maruz kaldığı psikolojik baskı da hissedilir. Toplumsal değerler her topluma özgü şekillenebilen davranış ve kültür biçimleri olarak ifade edilse de iftira atmak, yalan söylemek, dedikodu yapmak, hırsızlık yapmak gibi davranışların kötü ve toplumsal değerlere aykırı olduğu evrensel bir gerçektir. Yaşar Kemal bu eserinde değindiği bu cümlelerle kendini kandıran, kendi yaptığı yanlış davranışların farkında olup yapmaya devam eden insanların aşağılık kişiler olduğunu anlatır.

Yaşar Kemal Beyaz Pantolon isimli öyküsünde ise giymek istediği beyaz bir pantolon ve ayakkabıyı alabilmek için ağır bir işte çalışmak zorunda kalan Mustafa’yı anlatır. Karşısına çıkan Hasan Bey ona üç gün üç gece uyumadan devam edilecek fakat sonunda istediklerini alabilecek ücretin olduğu bir iş teklif eder. İşin ne kadar zor olduğunu hem annesinden hem de Cumali Amca'sından işitse de

"Mustafa durdu durdu, sonra kasabaya doğru birkaç adım attı. Ayakları geri geri gidiyordu sanki. Yürümekten vazgeçti. Gözünün önünden beyaz pantolonlar -ne olursa olsun, beyaz olsun da-, beyaz bulutlar, beyaz çamaşırlar, pamuk yığınları, bir sürü beyazhklar uçuşuyordu.” (Kemal Y. , 2007)

Cümleleri ile Mustafa'nın beyaz pantolon hayalinin ne kadar masum ve güçlü olduğu görülür. Fakat öyküde gece gündüz çalışan Mustafa'nın Cumali’nin kıskançlı̆̆ına ve tuzaklarına düştüğü görülür. Hasan Bey'in gelmesine yakıt vakitlerde Mustafa'yı dinlenmeye yollayan Cumali, işin sonunda gece gündüz çalışan Mustafa’nın hakkı olan iki günlük yevmiyeyi de alır. Hak yemek, kul hakkına girmek toplumsal değerler açısından büyük önem taşır. Mustafa'nın emeklerinin hakkının yendiği, iş yerindeki kıskanç ve kötü kalpli birinin tuzağına düştüğünü aktaran eser en sonunda hayallerine kavuşup Beyaz Pantolon ve yazlık ayakkabı alan Mustafa karakteriyle dürüstlük, çalışkanlık ve azim gibi değerlerin ne kadar kyymetli olduğunu anlatır.

Yeşil Kertenkele isimli öyküsünde ise babası belli olmayan İbrahim'in kendisi ile dalga geçen yaşıtlarından kaçarak doğaya ve hayvanlara sığınması konu edilir. İstanbul'da geçen Kalemler isimli eserinde ise başkahraman olan Neriman'ın kendisini okuldaki arkadaşlarına kalemleri ile kabul

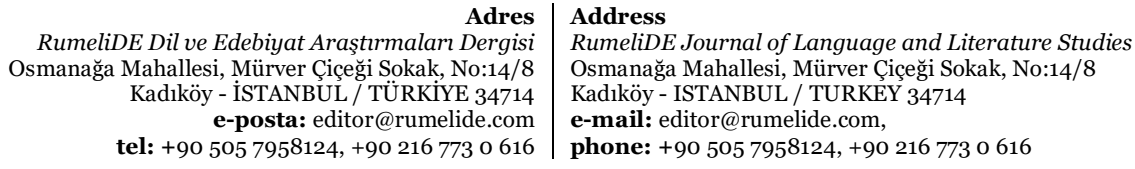


ettirmeye çalışması anlatılır. Neriman'a kalemleri çöpçü olarak çalışan babası çöplükten toplayıp vermektedir. Neriman'ı kıskanan arkadaşları ise Neriman'ın kalemlerini çaldığını iddia ederek onu okul müdürüne şikâyet etmektedir. Neriman kendisini düştüğü durumdan kurtarmak için yalan söyleyerek bu yalanı babasının da devam ettirmesini ister. Kızının üzülmesini istemeyen baba bu isteği kabul eder. Bu eserde Neriman'ın hayal dünyası ile çocuk psikolojisi, çevredeki kötülükler, insanların haset ve kıskançlıkları aktarılırken aynı zamanda iftira ve toplum içerisindeki eşitsizlik dikkat çekmektedir (Kemal Y. , 2007).

Şahan Ahmed isimli öyküsünde de umutla, dişiyle, tırnağıyla çabalayan Ahmed’in bu çabalar sonucunda elde ettiği tarlasını Ahmed’i kıskanan köylülerin şikâyetiyle ağaya kaptırması anlatılmıştır. İnsanoğlunun zalimlikleri ile karşı karşıya kalan Ahmed’in kendisine yapılan kötülüklere karşı

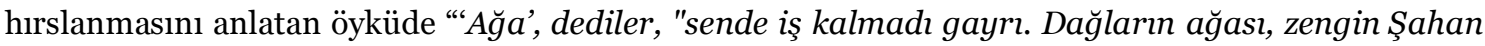
Ahmed oldu. Diyor ki, bu tarla bende varken, Ağa da ben paşa da." Cümleleri ile insanların kıskançlık ile bir insanın emeklerini, çabalarını, alın terini nasıl çöp ettikleri görülmektedir. Yeni bir tarla açmak için başkaldıran ve hırslanan Ahmed'in bu isyanı Yaşar Kemal'in romanlarındaki direnişlerin yanında oldukça sönüktür.

\section{Sonuç}

Yaşar Kemal, eşitsizliğin hüküm sürdüğü, hakkaniyetin olmadı̆̆ı ve ağalar tarafından halkın baskılandığı, küçük görüldüğü, katillerin her geçen gün arttı̆̆ı, toplumun giderek fakirleştiği, şiddetin dozunun yükseldiği ve insani değerlerin görmezden gelindiği bir ortama tanıklık etmiş bir yazardır. Maruz kaldığı bu ortam onun eserlerinin şekillenmesinde büyük rol oynamıştır. Yaşar Kemal, bilişsel ve duygusal tablosu ve kendi gözlem yeteneği ile kendi çocukluğunda maruz kaldığı olayları, çevresinde seyreden olaylar ile sentezleyebilme yeteneğine sahiptir. Bu yeteneği ile toplumda gözlemlediği tüm kötülükleri karakterler üzerinden okuyuculara aktarmayı hedefleyen Yaşar Kemal, hemen hemen tüm eserlerinde insani ve toplumsal değerlere dair yansıtmalarda bulunurken aynı zamanda bir toplumun sanat ve edebiyat yolu ile geliştirilebileceğine, değiştirilebileceğine olan inancını da vurgulamaktadır.

Toplumsal yaşam içerisindeki birçok değere ve ögeye dokunan Yaşar Kemal eserlerinden bir kısmının incelemeye tabi tutulduğu bu çalışmada, eserlerin zengin bir kültürel çerçevede şekillendiğini, insan sevgisinin ön planda tutulduğu, eserler içerisinde yer verilen kötü karakterler ile bir toplum içerisinde neyin olmaması, neyin doğru neyin yanlış değerlendirilmesi gerektiğini okuyucunun vicdan mahkemesine bırakmaktadır. Çoğu eserinde anlatıcı olarak karşımıza çıkan Yaşar Kemal, genel olarak haksızlı̆̆a uğramış, adaletsizliğe maruz kalmış kişilerin yanında dururken aynı zamanda sefalet ile mücadele ile kadın ve çocukların da maruz kaldıkları olaylar üzerinde durmuştur. Özgürlük, umut ve mutluluk değerleri kapsamında birçok anlamlı mesajı okuyucu ile buluşturan Yaşar Kemal, en dayanılmaz acıların yaşandığı durumlarda bile umut ve insan sevgisinin altını çizmiştir. Doğa, kadın, çocuk temelleri üzerinde olayları aktarmayı tercih eden Yaşar Kemal, insan ilişkilerinin en önemli belirleyicilerinin sevgi ve insani değerler olduğunu savunur. Ağaların halka zulmü ile bürokrasideki acımasız yaklaşımları, kapitalist dünyanın, zengin ve fakir ayrımını, ezilen köylünün ve sömürgecilerin zulmünü ele alan eserleri, insan ve toplumun gerçekliği yansıtan bir ayna görevi görür. Yaşar Kemal'in Anadolu'nun gerçekliğini gözler önüne serdiği ve karakterleri ile okuyucunun içini ısıttı̆̆ı öykülerinde Çukurova'nın tüm özellikleri görülebilmektedir. Yaşar Kemal'in öykülerindeki karakterlerinin hiçbiri çevre ve doğadan bağımsız değildir. Öykülerin karakterleri içerisinde özellikle çocuklar önemli bir yer tutmaktadır. Sarı Sıcak, Beyaz Pantolon, Yeşil Kertenkele öykülerinde kahramanlar çocuk karakterlerdir.

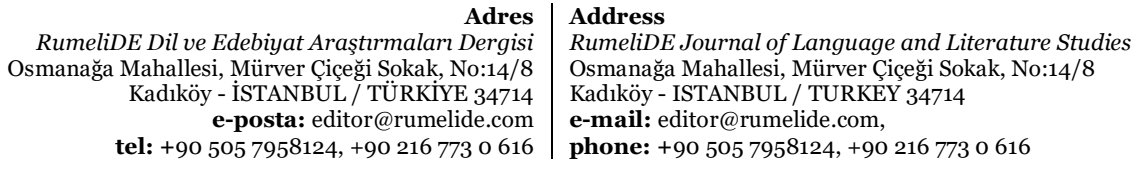


İnsan hem toplumla hem de doğa ile mücadele ederek ruhsal derinlikleri bu mücadele ile çizilmektedir. Karakterlerin hemen hemen hepsi zorluklar karşısında direnmesini bilen kişiler olsa da karakterlerin romanlardaki kadar değişim göstermediği ve baş kaldırmadıkları dikkat çekmektedir. "Sarı Sıcak" isimli öyküsünün başkahramanı olan Osman'ın yaşadığı acılar, “Beyaz Pantolon” isimli eserindeki Mustafa’ya yapılan, "Şahan Ahmed” öyküsündeki Ahmed'e yapılan haksızlıklar, "Ağır Akan Su” öyküsünde ise Kerem Usta’nın maruz kaldığı iftiralar ile İnce Memed'e ya da Salman’a dönüşmesi beklenmektedir. Fakat öykü karakterlerinde kişilerin romanlardaki başkaldıran kahramanlardan öncesinde nelere maruz kaldığı, onları doğuran asıl sebeplerin neler olduğu görülmektedir. Sefaletin, öfkelerin, hayallerin ve umutların dile getirildiği öykülerde karakterler mücadeleden çok kaçarak kurtulmayı çözüm olarak bulmuşlardır.

İnsan haklarının ve özgürlüğünün savunulduğu eserlerinde ülkesinin gerçeklerine sırtını dönmeyen bir yazar olan Yaşar Kemal, kişilerin de aynı şekilde bu gerçeklere hem gözlerini hem de vicdanlarını kapamaması gerektiğini ve insani değerlerin kazanılmasında, yeni nesillere aktarılmasında edebiyatın yadsınamaz bir öneminin olduğunu vurgulamaktadır. Okuyucusunun kendi içerisinde bir mahkeme kurmasına izin veren Yaşar Kemal'in en büyük mirası olan eserlerinin insanî değerler, barış ve adalet mücadelesinde günümüzde de önemli bir ilham kaynă̆ı olduğunu söylemek doğrudur.

\section{Kaynakça}

Özbay, M., \& Karakuş Tayşi, E. (2011). Dede Korkut Hikâyeleri'nin Türkçe Öğretimi ve Değer Aktarımı Açısından Önemi. Pegem Eğitim ve Öğretim Dergisi, 1(1), 21-31.

Özbay, M., \& Kurtuluş Tayşi, E. (2009). Dede Korkut Hikâyelerinin Türkçe Öğretimi ve Değer Aktarımı Açısından Önemi. Pegem Eğitim ve Öğretim Dergisi,, 21-31.

Akbalık, H. (2015). Değerler Eğitimi Bağlamında Hacı Bektaş-ı Veli’nin Eserlerinde Yer Alan Eğitsel Unsurlar. Atatürk Üniversitesi Eğitim Bilimleri Enstitüsü Türkçe Eğitimi Ana Bilim Dalı Yüksek Lisans Tezi.

Ali, S. (2003). Sulfata. Yeni Dünya (s. 129). içinde Yapı Kredi Yayınları.

Ali, S. (2019). Köpek. Kağnı-Ses. içinde Karbon Kitaplar.

Arseven, T. (2018). Yaşar Kemal'in "Yılanı Öldürseler" Adlı Romanı Üzerine Bir İnceleme. Folklor / Edebiyat Dergisi, 24(95).

Avcı, N. (2007). Toplumsal Değerler ve Gençlik. Ankara: Siyasal Kitabevi.

Aydın, M. Z., \& Akyol Gürler, Ş. (2012). Okulda değerler eğitimi yöntemler-etkinliklerkaynaklar. Ankara: Nobel Akademik Yayıncllı.

Demirtaş, T. (2012). Değerler Eğitiminde Edebi Ürünlerden Yararlanma: Nasrettin Hoca Fikraları. Sakarya Üniversitesi Eğitim Bilimleri Enstitüsü Türkçe Eğitimi Ana Bilim Dalı Yüksek Lisans Tezi.

Demiryürek, G. (2015). Çağdaş Çocuk Şiirinde Değerler Eğitimi (1980’den Günümüze). Atatürk Üniversitesi Eğitim Bilimleri Enstitüsü Türkçe Eğitimi Ana Bilim Dalı Doktora Tezi.

Deveci, H., Belet, D., \& Türe, H. (2013). Dede Korkut Hikayelerinde Yer Alan Değerler. Elektronik Sosyal Bilimler Dergisi Elektronik Sosyal Bilimler Dergisi, 12(46), 294-321.

Erden, A. (1993). Sarı Sıcağın Acımasız Yüzü. Hacettepe Üniversitesi Edebiyat Fakültesi Dergisi, 10(1), 87-104.

Esendal, M. Ş. (2005). Doktor Savdur. Bir Kucak Çiçek. içinde

Esendal, M. Ş. (2007). Bayram Günleri. Gödeli Mehmet. içinde

Göz, K. (2014). Toplumsal Değerler Bakımından Yaşama Hürriyeti. Pamukkale Üniversitesi İlahiyat Fakültesi Dergisi, 85-201.

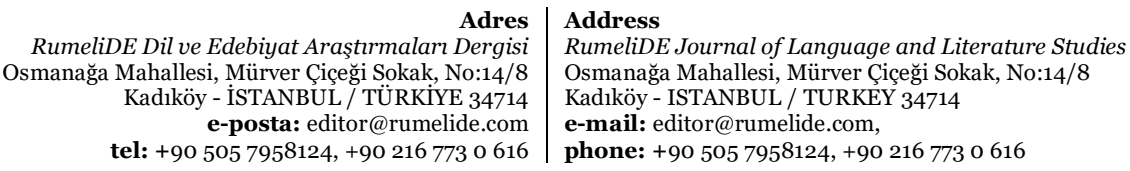


Güngör, E. (1993). Değerler Psikolojisi. İstanbul.

Güngör, E. (2010). Değerler Psikolojisi Üzerinde Araştırmalar. İstanbul: Ötüken Yayınları.

Han, C., \& Türkyılmaz, M. (2020). The Analyse Of Miyase Sertbarut's Novels In Terms Of Value Transfers. Türk Akademik Yayınlar Dergisi, 4(2), 122-151.

Hanım, F. A. (2012). Muhadarat. İstanbul: Özgür Yayınları.

Karaca, Ş. (2011). Fatma Aliye Hanım’ın Türk Kadın Haklarının Düşünsel Temellerine Katkılar. Karadeniz Araştırmaları, 31, 93-110.

Kemal, O. (2008). Ekmek Kavgasi.

Kemal, Y. (1998b). Deniz Küstü. İstanbul: Adam Yayıncllı.

Kemal, Y. (2000a). İnce Memed. İstanbul: Adam Yayıncıllk.

Kemal, Y. (2000e). Ağrıdağı Efsanesi. İstanbul: Adam Yayıncılık.

Kemal, Y. (2000g). Al Gözüm Seyreyle Salih. İstanbul: Adam Yayıncılık.

Kemal, Y. (2007). Ağır Akan Su. Sarı Sıcak. içinde

Kemal, Y. (2007). Beyaz Pantolon. Sarı Sıcak. içinde

Kemal, Y. (2007). Yeşil Kertenkele. Sarı Sıcak. içinde

Kenan, S. (2007). Modern eğitimin oluşum sürecinde değerler eğitimi nasıl zayıfladı? R. Kaymakcan, S. Kenan, H. Hökelekli, Ş. Aslan, \& M. Zengin içinde, Değerler ve eğitimi uluslar arası sempozyumu (s. 279-295). İstanbul: Dem Yayınları.

Keskin, Y. (2016). Değerler Hakkında Genel Bilgiler. M. Köylü içinde, Teoriden Pratiğe Değerler Ĕgitimi (s. 19-101). Ankara: Nobel Yayınları.

Meydan, H. (2014). Okulda Değerler Eğitiminin Yeri ve Değerler Eğitimi Yaklaşımları Üzerine Bir Değerlendirme. Journal of Theology Faculty of Bülent Ecevit University, 1(1), 93-108.

Nichanian, M. (2011). Edebiyat ve Felaket. İstanbul: İletişim Yayınları.

Sadak, Y. (2017). Yaşar Kemal ya da Dionysos’un Dönüşü. İstanbul: Öteki Yayınları.

Sallabaş, M. E. (2012). Mustafa Kemal Üniversitesi Sosyal Bilimler Enstitüsü Dergisi. Ömer Seyfettin Hikayelerinin Türkçe Öğretiminde Değer Aktarımı Bakımından İncelenmesi, 9(18), 59-68.

Şimşek, Ş. (2015). Kemalettin Tuğcu'nun Romanlarında Değerler Eğitimi. International Journal of Humanities and Education, 1(1), 79-104.

Yaşar, K. (2007). Bebek. Sarı Sicak. İstanbul : Yapı Kredi.

Yaşar, K. (2007). Pis Öykü. Notos Kitap Yayınevi.

RumeliDE Dil ve Edebiyat Araştırmaları Dergisi Osmanağa Mahallesi, Mürver Çiçeği Sokak, No:14/8 Kadıköy - İSTANBUL / TÜRKIYE 34714 e-posta: editor@rumelide.com tel: +90 $5057958124,+902167730616$
Address

RumeliDE Journal of Language and Literature Studies

Osmanağa Mahallesi, Mürver Çiçeği Sokak, No:14/8

Kadıköy - ISTANBUL / TURKEY 34714

e-mail: editor@rumelide.com,

phone: +90 5057958124, +90 2167730616 